\title{
Rugby team converts to give gene tests a try
}

Carina Dennis, Sydney

An Australian rugby league team claims it has gained a competitive edge over its rivals by using genetic tests to tailor its players' training programmes. This move marks the beginning of more widespread use of genetics in sport, according to geneticists and legal experts.

"Once one club has it, there will be pressure on other teams to do everything they can or risk falling behind the technology," says David Weisbrot, president of the Australian Law Reform Commission, which makes legislative and policy recommendations regarding genetic information to the nation's government.

The Sea Eagles, a professional rugby team in Manly, a seaside suburb of Sydney, has DNA-tested 18 of its 24 players for 11 exercise-related genes. Some of the genes tested are associated with the efficiency of oxygen use; others are involved in muscle development and clearing lactate, the chemical that causes muscle stiffness.

Each player's training programme is being redesigned according to whether his individual genetic profile indicates, for example, that his main strength is endurance or speed. "We don't want a player running 100 kilometres a week if his genes say he's more suited to 50 kilometres a week and

\section{IMAGE UNAVAILABLE FOR COPYRIGHT REASONS}

$\mathrm{He}$ is working with the Australian Institute of Sport (AIS), the country's premier sports training and research facility, to develop genetic profiles that identify the sport best suited to an athlete. Genetic indicators of speed, power and endurance can inform decisions about whether an athlete is better suited to swimming or rowing, for instance.

Trent's team is also investigating genetic profiles to position rugby union players on the field - for example, whether they are better suited to being nimble backs or beefy forwards.

There could soon be pressure on sports clubs, for financial and insurance reasons, to extend their testing to screen for genetic predisposition to certain injuries,

doing more weights," says Steve Dank, the team's physiologist behind the programme.

But applying genetics to sports training is premature, say some experts. "We don't know enough yet about these genes," says Ron Trent, a molecular geneticist at the University of Sydney.

Trent also argues that genetic tests are likely to be "more meaningful at the élite level, where it could be the difference between a gold and silver Olympic medal". But he agrees that they could help to identify an athlete's potential.
Weisbrot says. "I also have concerns about privacy and genetic discrimination," he adds.

DNA samples are destroyed immediately after testing and the team has agreements in place to stop the information being obtained by other parties, according to Dank.

Dank believes that genetic screening will become routine for sports clubs - "I've had a number of clubs contact me," he says. But he doubts that they will ever be critical factors in selecting players. "Gene tests don't measure the passion that makes players great,"he says.

\section{Japan plans blood-donor restrictions to combat vCJD}

Ichiko Fuyuno, Tokyo

Japan is considering a tough new rule to prevent the spread of new-variant Creutzfeldt-Jakob disease (vCJD), the human equivalent of mad cow disease.

If the rule passes when an advisory committee addresses it again in a few months' time, it would ban anyone who spent even a single day in Britain or France between 1980 and 1996 from giving blood. This would further tighten current restrictions, which bar people who have spent more than one month in those countries, and is expected to hugely reduce the number of eligible donors.

Other countries have taken similar, if less cautious, measures. The United States, for example, does not allow people who have lived in Britain for several months to give blood. But Japan's new rule, proposed by an advisory committee to the ministry of health on 7 March, is the most stringent yet. "We are taking the safest possible measure until the risk is further determined," says Daisaku Sato, deputy director of the ministry's blood and blood-products division.

The proposed change reflects fears that arose after ministry officials announced the first confirmed case of vCJD in Japan in early February: the man was thought to have been infected during a stay of less than a month in Britain around 1990. He began to show symptoms in 2001, and died in December last year.

About 160 people have died from vCJD around the world, mostly in Britain. Until now, most fatalities have occurred among people who had lived in the country for at least a few years. The disease is thought to be caused mainly by eating meat infected with rogue proteins called prions, but there have been at least two cases of probable infection from blood transfusions.

Government officials and scientists are keen to determine how many people are carrying the disease without symptoms, and what the chances are that such people may transmit the disease through transfusions or surgery. In Britain, steps have been taken to reduce the risk - such as removing white blood cells from transfusion products. British blood banks are also considering filtering blood for prions, or restricting donors to low-risk age groups. But these options are expensive and severely limit blood supplies.

The Japanese Red Cross Society estimates that the new rule would cost it hundreds of thousands of potential donors. "The damage would be significant," says a spokesman.

And Masahito Yamada, a prion-disease specialist at Kanazawa University, says that the ministry's efforts may have a limited effect as Japan relies on imports for many blood products. This poses concerns that contaminated blood could still enter Japan. "It is really important to establish a safe global distribution system for blood products," Yamada says. 